\title{
A 94-10 ka pollen record of vegetation change in Qaidam Basin, northeastern Tibetan Plateau
}

\author{
Haicheng Wei ${ }^{\mathrm{a}}$, Qishun Fan ${ }^{\mathrm{a}}$, Yan Zhao ${ }^{\mathrm{b}}$, Haizhou Ma ${ }^{\mathrm{a}}$, Fashou Shan ${ }^{\mathrm{a}}$, Fuyuan An ${ }^{\mathrm{a}}$, Qin Yuan ${ }^{\mathrm{a}}$ \\ a Qinghai Institute of Salt Lakes, Chinese Academy of Sciences, Xining 810008, China \\ b Institute of Geographic Sciences and Natural Resources Research, Chinese Academy of Sciences, Beijing 100101, China
}

\section{A R T I C L E I N F O}

\section{Article history:}

Received 19 May 2014

Received in revised form 27 March 2015

Accepted 24 April 2015

Available online 4 May 2015

\section{Keywords:}

Pollen record

Climate change

Qaidam Basin

Late Pleistocene

Tibetan Plateau (TP)

\begin{abstract}
A B S T R A C T
Drill core (ISL1A) was obtained from the Qarhan Salt Lake in central eastern Qaidam Basin, northeastern Tibetan Plateau (NE TP). Fossil pollen and the lithology of the core sediment were analyzed in conjunction with AMS ${ }^{14} \mathrm{C}$ and ${ }^{230}$ Th dating. The results indicated that Artemisia and Chenopodiaceae dominated the steppe/desert steppe vegetation developed around the lake between 94 and $51.2 \mathrm{ka}$, corresponding with the organic-rich silty clay deposited in the core sediments. Pediastrum continuously appeared in the core sediments between 94 and 51.2 ka, indicating freshwater to oligohaline conditions of the paleo-Qarhan Lake during the late marine isotope stage (MIS) 5, MIS 4, and early MIS 3. During the 51.2 to 32.5 ka period, Ephedra dominated shrub-desert vegetation expanded in the basin, while, Pediastrum disappeared in the core sediments. The core sediments consisted of interbedded layers of halite silt and clay-rich halite between 51.2 and $32.5 \mathrm{ka}$, signifying a shift toward drier hydrologic conditions. Thus, the paleo-Qarhan Lake experienced periods of desiccation and shallow water levels. Artemisia and Chenopodiaceae dominated steppe/desert steppe vegetation appeared again from 32.5 to $25.3 \mathrm{ka}$, with clay-rich sediments in the core, thereby suggesting an increase of runoff from the lake under relatively wetter climatic conditions. Since $25.3 \mathrm{ka}$, however, pollen concentrations declined, corresponding with the amount of halite deposited in the core sediment and, suggesting a cold, dry climatic condition during MIS2. Our findings have important implications for understanding complex regional vegetation and climatic responses to large-scale forcings in the Qaidam Basin.
\end{abstract}

(c) 2015 Elsevier B.V. All rights reserved.

\section{Introduction}

The northeastern Tibetan Plateau (NE TP), located at a triple junction of influences that include the Asian summer monsoon, the westerly jet stream and the Siberian high, is of considerable significance with regard to regional responses to global climate change. The Qaidam Basin is a large intermontane endorheic basin at the NE TP and is enclosed by three large mountain belts, the Altun Mountains in the northwest, the eastern Kunlun Mountains in the south and the Qilian Mountains in the northeast. The Qaidam Basin covers an area of $120,000 \mathrm{~km}^{2}$, has an elevation of $2800 \mathrm{~m}$ a.s.l. and has a catchment of approximately $250,000 \mathrm{~km}^{2}$ (Chen and Bowler, 1986) (Fig. 1A).

Qarhan Salt Lake is the largest playa located in the central eastern Qaidam Basin, NE TP (Fig. 1A), an area characterized by a very thick sequence of Quaternary sediments that exceed $3000 \mathrm{~m}$ in places (Liu et al., 1998). Continuous lacustrine sediments may provide excellent archives of detailed paleo-environmental data regarding climatic change in the NE TP. Over the past three decades, significant research efforts have been directed toward investigating halite mineral, paleo-climate and

E-mail addresses: hcwei@isl.ac.cn, weihaicheng_1984@126.com (H. Wei). the evolutionary history of salt lakes in the Qaidam Basin (Chen and Bowler, 1986; Zhang, 1987; Chen et al., 1990; Huang and Chen, 1990; Zhang et al., 1993, 2007; Zhao et al., 2007; Liu et al., 2008; Fan et al., 2010); however, the Late Pleistocene paleoclimatic variation in the eastern Qaidam Basin is still largely unclear due, in part, to limited numbers of long-sequenced paleoclimatic records. Most previous records extend only as far back as the late glacial or early Holocene Epoch (Zhao et al., 2007, 2008; Liu et al., 2008), although there are a few low resolution paleoclimatic records extending back to the last glacial or the Late Pleistocene (Chen and Bowler, 1986; Chen et al., 1990; Huang and Chen, 1990; Zhang et al., 1993; Yang et al., 1995). Beyond some paleoclimatic records of sediment cores in the Qarhan Salt Lake area, the Shell Bar, located in the southeastern margin of the Qarhan Salt Lake, has been regarded as better geomorphic evidence to reflect the evolutionary history of the Qarhan paleolake (Chen et al., 1990). Zhang et al. (2007) reconstructed the lake level history and climatic change of the Qarhan paleolake based on dating results and multi-proxies analysis of the Shell Bar and revealed that there were relatively humid climatic conditions during marine isotope stage 3 (MIS3), which corresponded to a mega-paleolake preserved in Qaidam Basin. However, new studies of the Shell Bar dating to MIS 5 (Lai et al., 2014) indicate that, regardless of its age, the Shell Bar is not related to a lake but rather to a stream 


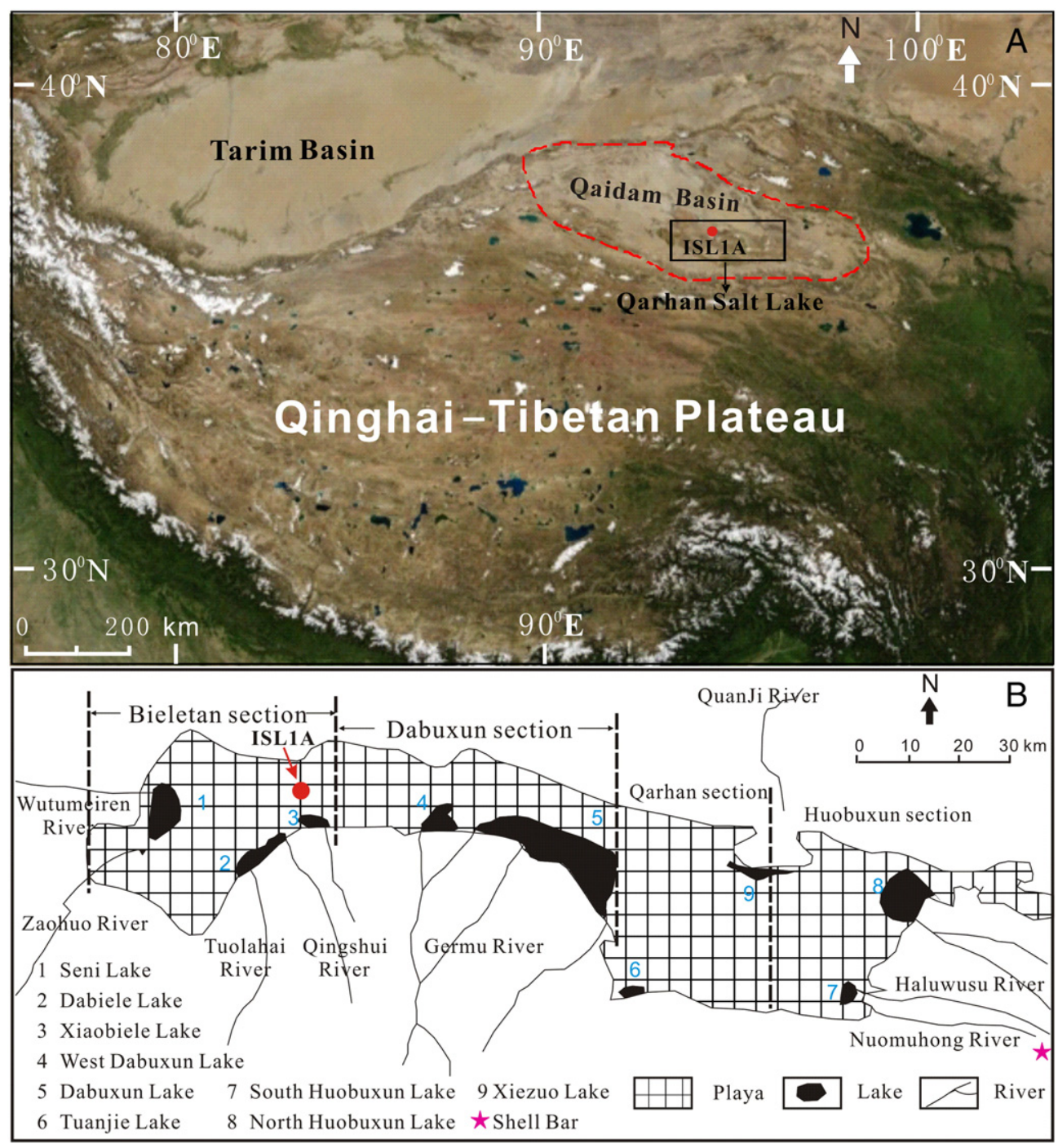

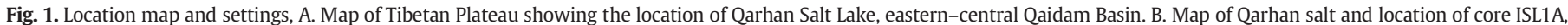
modified from Fan et al. (2014b).

deposit (Mischke et al., 2014). Meanwhile, Madsen et al. (2014) propose that the highest shoreline in Da Qaidam dates to MIS 5 or earlier.

These low resolution paleoclimate records of lacustrine deposits, together with various geomorphic and sedimentological explanations for the Shell Bar, still cannot explain how the Qarhan mega-paleolake formed and evolved during the Late Pleistocene. Furthermore, there are no high resolution pollen records covering the glacial/interglacial cycles from lacustrine deposits in the Qarhan Salt Lake. Thus, the history of vegetation and climate change during the Late Pleistocene in the central eastern Qaidam Basin is poorly understood. This study, which was compiled from the core $102 \mathrm{~m}$ in length, provides the first high resolution pollen record covering the entire late part of the last interglacial period and last glaciation period in central eastern Qaidam Basin. Our objectives were to reconstruct the regional vegetation change and climatic variability during the Late Pleistocene and to provide insights regarding the evolution of the Qarhan Salt Lake during the Late Pleistocene.

\section{Physical setting}

Qarhan Salt Lake $\left(36^{\circ} 37^{\prime} 36^{\prime \prime}-37^{\circ} 12^{\prime} 33^{\prime \prime} \mathrm{N}, 94^{\circ} 42^{\prime} 36^{\prime \prime}-96^{\circ} 14^{\prime} 35^{\prime \prime} \mathrm{E}\right)$ is the largest playa in the Qaidam Basin (Fig. 1B). The distance from west to east is approximately $168 \mathrm{~km}$ and the distance from north to south ranges between 20 and $40 \mathrm{~km}$, thus, covering an area of approximately
$5856 \mathrm{~km}^{2}$ (Chen and Bowler, 1985, 1986). The Qarhan Salt Lake was a depositional center of Qaidam Basin during the Quaternary, with lacustrine deposits reaching $3000 \mathrm{~m}$ in thickness (Liu et al., 1998). The lake has an elevation of $2675 \mathrm{~m}$ a.s.l. at the lowest point in the depression (Chen and Bowler, 1985). From west to east in this playa, the Qarhan Salt Lake is divided into four sections Bieletan, Dabuxun, Qarhan and Huobuxun (Fig. 1B). The Qarhan Salt Lake distributes to 10 brine lakes around the playa, and the field investigation indicates that there are 18 rivers originating from the Kunlun Mountain to feed into the Qarhan Salt Lake (Yu et al., 2009). The landforms are composed of wind-erosion yardangs, salt lake playas, aeolian deposits, and Gobi from west to east.

The Qarhan Salt Lake area is one of the driest places in the world with a mean annual temperature of $5.33^{\circ} \mathrm{C}$, a mean annual precipitation level of approximately $24 \mathrm{~mm}$ and an annual potential evaporation level of approximately $3564 \mathrm{~mm}$, according to climate averages at reported at the Qarhan meteorologic station (Fan et al., 2014a). However, the mean annual precipitation on the northern slopes of the Kunlun Mountain is slightly greater than that of the Qarhan Salt Lake. Additionally, the average wind speed is $4.3 \mathrm{~m} / \mathrm{s}$ and relative moisture is $27.7 \%$ (Yu et al., 2009). The vegetation types surrounding Qarhan Salt Lake vary with altitude. Between 2700 and $3700 \mathrm{~m}$, the vegetation is characterized by typical desert vegetation and halophilous species, mainly Salsola abrotanoides, Kalidium gracile, Halostachys caspica, Ephedra przewalskii, Nitraria tangutorum, Calligonum mongolicunl and Tamarix chinensis. 
Poaceae and Cyperaceae-dominated meadow are scattered on the southern side of the Qarhan Salt Lake Playa where groundwater seeps out. Aquatic plant taxa along the river bank are mainly Phragmites communities, Typha spp., Ruppia spp. and Potamogeton spp. With increasing distance from the Qarhan Playa south to the Kunlun Mountain, at 3600 to $4100 \mathrm{~m}$, the alpine steppe is composed of Stipa purpurea, Asteraceae (including Artemisia spp., Ajania fruticulosa and Asterothamnus centraliasiaticus), Oxytropis ochrocephala, Potentilla fruticosa, Clematis florida, and Brachanthemum gobicum. Alpine desert with scattered Ceratoides compacta, tibet ajania Alchemilla and Saussurea medusa is restricted to the Kunlun Mountains at an elevation between 4100 and $4700 \mathrm{~m}$ (Hou, 2001).

\section{Materials and methods}

\subsection{Sediment core and dating}

The ISL1A core $\left(37^{\circ} 3^{\prime} 50^{\prime \prime} \mathrm{N}, 94^{\circ} 43^{\prime} 41^{\prime \prime} \mathrm{E}\right)$ was obtained from west of the Qarhan Salt Lake (Fig. 1B). The lithostratigraphy of the core alternates primarily between evaporite layers and silt-clay sediment layers from 0 to $51.1 \mathrm{~m}$, and between fresh-water silt and organic-rich clay sediments from 51.1 to $102 \mathrm{~m}$ (Fig. 2).

Twelve clay samples containing dark organic matter were collected from the upper $54.5 \mathrm{~m}$ of the core for accelerator mass spectrometry (AMS) ${ }^{14} \mathrm{C}$ dating, and eight halite samples were collected from the upper $46.0 \mathrm{~m}$ of the core for ${ }^{230} \mathrm{Th}$ dating. An assessment and comparison of these ${ }^{230} \mathrm{Th}$ and $\mathrm{AMS}{ }^{14} \mathrm{C}$ ages have been discussed in detail in another paper (Fan et al., 2014b). In addition, three carbonate samples were collected from 64.5 to $98.9 \mathrm{~m}$ of the core for isochron ${ }^{230} \mathrm{Th}$ dating. The impure carbonate samples were dissolved with $0.1 \mathrm{M} \mathrm{HCl}, 1 \mathrm{M} \mathrm{HCl}$ and $\mathrm{HF}-\mathrm{HClO}_{4}$, respectively, to obtain isochron ${ }^{230} \mathrm{Th}$ ages. Chemical procedures followed those described by Ma et al. (2004, 2010a,b).
${ }^{230}$ Th ages of carbonate deposits were determined using an Octête® plus alpha spectrometer, with a vacuum of $20 \mathrm{mT}$ and an energy resolution (FWHM) of approximately $25 \mathrm{keV}$ at $5.15 \mathrm{MeV}$. Analyses were conducted at the U-series Dating Laboratory of The Institute of Geology and Geophysics, Chinese Academy of Sciences.

\subsection{Laboratory work and pollen analysis}

Approximately $10 \mathrm{~g}$ of sediment from each of the 143 subsamples was used for pollen analysis. Pollen subsamples were sieved and then subject to flotation in a heavy liquid solution $(\mathrm{KI}+\mathrm{HI}+\mathrm{Zn})$ with a specific gravity of approximately $2.0 \mathrm{~g} / \mathrm{ml}$ to extract pollen from sediments, followed by acetolysis treatment as described in Moore et al. (1991). Pollen concentration values were calculated by adding Lycopodium tablets to weighed sediment samples. Pollen taxa were identified under an optical microscope at $\times 400$ magnification and $\times 1000$ magnification was used for critical identifications. Pollen sums were usually $>300$ terrestrial pollen grains. Identifications followed Wang et al. (1995) and were aided by modern reference collections. Pollen percentages were calculated based on the total terrestrial pollen sum, while percentages of Pediastrum colonies were calculated based on the pollen sum plus Pediastrum counts. Pollen diagrams were plotted using Tilia 2.0.

\section{Result}

\subsection{Chronology}

Twelve AMS ${ }^{14} \mathrm{C}$ ages of total organic carbon (TOC) and eight ${ }^{230} \mathrm{Th}$ ages of halite in the upper $54.5 \mathrm{~m}$ of the sediment core of ISL1A were compared and discussed (Fan et al., 2014b). Three isochron ${ }^{230}$ Th ages of lake carbonates from 64.5 to $98.9 \mathrm{~m}$ in ISL1A were measured using the isotopic ratios of $U$ and Th among three fractions leachates $(\mathrm{L})$,

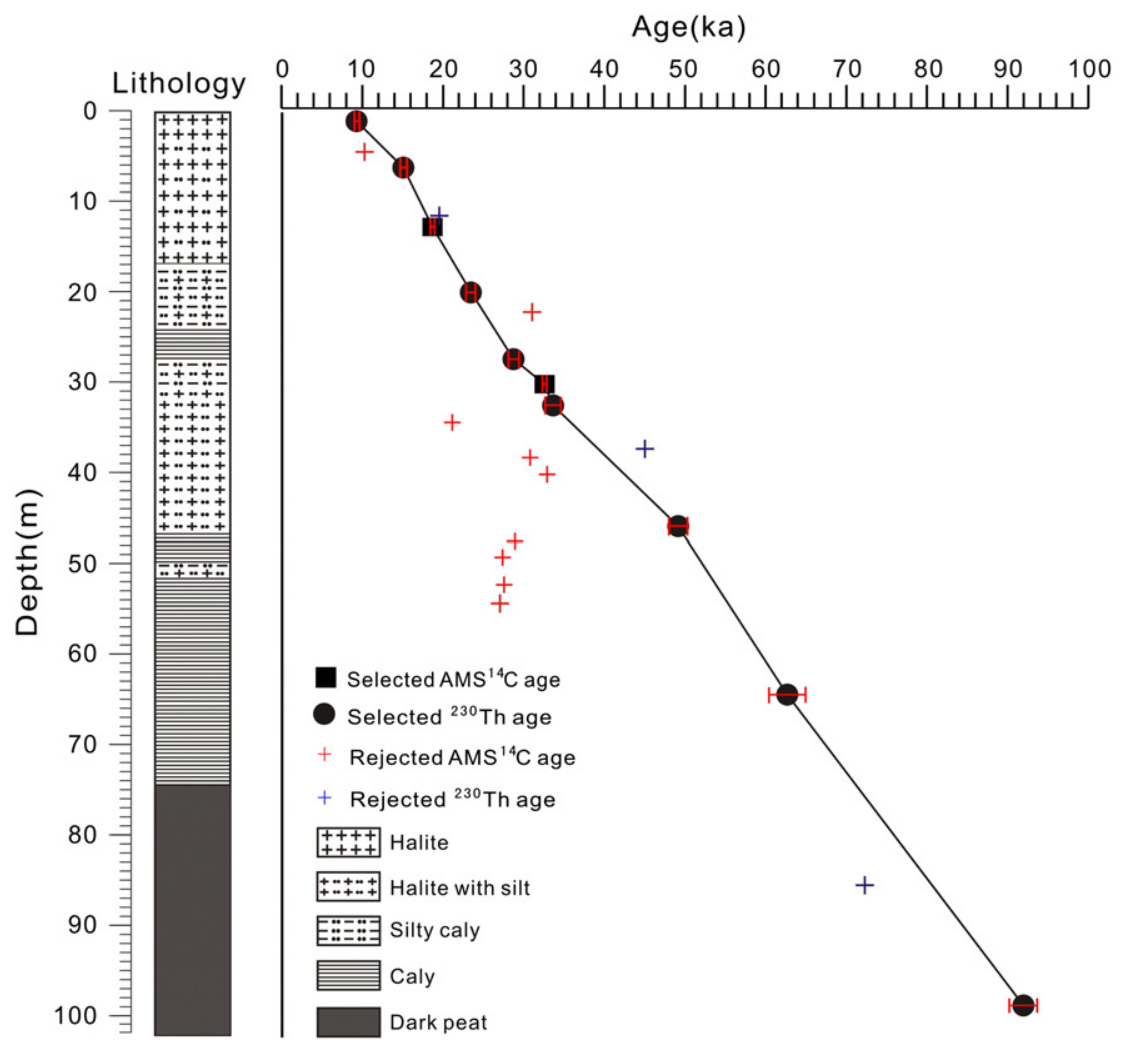

Fig. 2. Lithology and age-depth model based on U/Th and AMS ${ }^{14} \mathrm{C}$ dating of core ISL1A. 
residuals $(\mathrm{R})$ and whole-samples $(\mathrm{W})$. We employed this simple model to correct the initial ${ }^{230} \mathrm{Th}$ values of carbonate samples and calculated their ages by utilizing the ISOPLOT program (Ludwig, 1991). The details of ${ }^{230} \mathrm{Th}$ dating results are presented in Supplementary Table 1.

In this study, we first selected those ages in stratigraphic order to establish the age-depth framework in ISL1A (Fig. 2). By comparing ${ }^{230} \mathrm{Th}$ ages of halite with AMS ${ }^{14} \mathrm{C}$ ages of TOC in ISL1A, we found that the upper four AMS ${ }^{14} \mathrm{C}$ ages from 4.65 to $30.29 \mathrm{~m}$ are in good agreement with the upper six ${ }^{230} \mathrm{Th}$ ages from 0.35 to $32.29 \mathrm{~m}$ in this core. As presented in Fig. 2 , the AMS ${ }^{14} \mathrm{C}$ age $(8661 \pm 45 \mathrm{cal}$ a BP $)$ of TOC at a depth of $4.65 \mathrm{~m}$ is close to ${ }^{230} \mathrm{Th}$ ages $(8.2 \pm 0.3 \mathrm{ka})$ of halite at a depth of $0.35 \mathrm{~m}$. Thus, we chose the ${ }^{230} \mathrm{Th}$ ages $(8.2 \pm 0.3 \mathrm{ka})$ of halite at a depth of $0.35 \mathrm{~m}$ to establish the age of the top of the ISL1A core. Similarly, as the AMS ${ }^{14} \mathrm{C}$ age $19,087 \pm 65 \mathrm{cal}$ a BP at the depth of $13.01 \mathrm{~m}$ were in agreement with ${ }^{230} \mathrm{Th}$ age $19.4 \pm 0.8 \mathrm{ka}$ of halite at a depth of $12.01 \mathrm{~m}$, we chose the AMS ${ }^{14} \mathrm{C}$ age for the ISL1A chronology framework. However, the AMS ${ }^{14} \mathrm{C}$ age of TOC from $22.18 \mathrm{~m}$ and ${ }^{230} \mathrm{Th}$ age of halite from $37.21 \mathrm{~m}$ in this core was obviously older than that from other ages between 20.22 and $46.00 \mathrm{~m}$. Thus, we rejected those two ages. AMS ${ }^{14} \mathrm{C}$ ages at 30.29 to $54.50 \mathrm{~m}$ were constant or younger with increasing depth. Therefore, we argue that AMS ${ }^{14} \mathrm{C}$ ages of TOC and ${ }^{230} \mathrm{Th}$ ages of halite in the upper $30 \mathrm{~m}$ of lacustrine sediments are more reliable, while other AMS ${ }^{14} \mathrm{C}$ ages of TOC between 30.29 and $54.50 \mathrm{~m}$ of lacustrine sediments are underestimated due, in part, to the contamination by underground water (Fan et al., 2014b). Due to the U content of L fraction in a sample from $85.78 \mathrm{~m}$, which was found to be the lowest, and as such, the age of this sample was different from that of the other two samples obtained from $64.54 \mathrm{~m}$ and $98.90 \mathrm{~m}$. Therefore, we selected two isochron ${ }^{230} \mathrm{Th}$ ages of lake carbonates at 64.54 and $98.90 \mathrm{~m}$ to establish the age model (Fig. 2). In general, the age model in ISL1A is more reasonable.

\subsection{Lithology}

We describe the core sediment starting from the sediment surface using a centimeter scale. The top $17.73 \mathrm{~m}$ ( $22 \mathrm{ka}$ ) of the core sediments consist primarily of halite and halite with silt. The sediment between 17.73 and $21.73 \mathrm{~m}$ ( 22 to $25.3 \mathrm{ka}$ ) is marked by interbedded halite with a silt layer and silt. Between 21.73 and $31.57 \mathrm{~m}$ (25.3 to $32.5 \mathrm{ka}$ ) the sediments mainly consist of laminated gray silt-clay with two intercalated halite silt layers. The sediments consist of silt-rich halite and interbedded layers of halite silt between 31.57 and $47.36 \mathrm{~m}$ (32.5 to $50.2 \mathrm{ka}$ ). Between 47.36 and $74.29 \mathrm{~m}$ (50.2 to $71.6 \mathrm{ka}$ ), the sediments consist of laminated gray/green silty clay. A halite-gypsum silt layer is embedded in this silty clay section between 49.93 and $51.59 \mathrm{~m}$ (52.1 to $53.2 \mathrm{ka}$ ). The lowermost section, from 74.29 to $102.03 \mathrm{~m}$ (71.6 to $94.6 \mathrm{ka}$ ) consists primarily of dark organic-rich clay.

\subsection{Fossil pollen spectra}

A total of 67 pollen types are identified from the core ISL1A at Qarhan Salt Lake. A summary percentage pollen diagram with 33 selected taxa is presented in Fig. 3. Herbs and shrubs pollen taxa are dominant in the majority of the samples, ranging from $72.7 \%$ to $99.1 \%$, with an average of 93.3\%. They are characterized by a high level of Artemisia (7.0 to 63.2\%, average $31.5 \%$ ), Chenopodiaceae (4.3 to $53.4 \%$, average $23.9 \%$ ) and Ephedra ( 0 to $26.6 \%$, average $7.2 \%$ ). However, Poaceae, Cyperaceae, Asteraceae, Nitraria are also important components, while Ranunculaceae, Fabaceae, Brassicaceae, Elaeagnaceae, Thalictrum and Polygonaceae are frequently present. Arboreal pollen is less dominant, fluctuating between 0.9 and 27.3\%. A variety of types of arboreal pollen are present, including Picea, Pinus, Corylus, Betula and Cupressaceae.

The percentage pollen diagram is divided into five major pollen zones, including subzones when necessary, based on stratigraphically constrained cluster analysis (CONISS) (Grimm, 1987).

\subsubsection{Pollen zone A (94-72.6 ka; $101.28-76.34 \mathrm{~m}$ )}

Zone A is characterized by an abundance of herb pollen Artemisia and Chenopodiaceae. Zone A can be divided into two subzones A1 (94 to $83.5 \mathrm{ka} ; 101.28$ to $89.01 \mathrm{~m}$ ) and $\mathrm{A} 2$ (83.5 to $72.6 \mathrm{ka} ; 89.83$ to $76.34 \mathrm{~m})$.

The percentage of Artemisia in subzone A1 is relatively higher than that of Chenopodiaceae, the former fluctuating between 29.4 and 47.1\% (average $36.4 \%$ ) and the latter between 5.6 and 36.3\% (average $21.1 \%$ ). Ephedra is present throughout the zone, varying from 2.8 to 22.8\% (average 10.4\%), while Poaceae, Asteraceae and Cyperaceae ranged from 0 to 9.3\%. While Nitraria, Ranunculaceae, Fabaceae, Brassicaceae and Polygonaceae are frequently present, they total less than $2 \%$. Other mesic to arid shrubs and herbs, such as Tamaricaceae, Elaeagnaceae, and Thalictrum are sporadically present in a few samples. Arboreal pollen is dominated by Picea, Pinus, Cupressaceae and Betula. Conifer, including Picea and Pinus, ranges from 0 to $3.9 \%$, while Cupressaceae is present almost throughout the zone, but had a mean of only $1.7 \%$. Betula is present in only a few samples, varying from 0 to $2.1 \%$. While Pediastrum appears frequently, most of the samples indicate amount less than $2.3 \%$. In subzone A2, Artemisia decreases slightly compared to zone A1, while Chenopodiaceae increases moderately and Ephedra is stable but low (average 6.9\%). The amount of Pediastrum increases distinctly in subzone A2 compared to that of zone A1 (average $12.6 \%)$.

\subsubsection{Pollen zone B (72.6-61.7 ka; 76.34-63.49 m)}

In zone $\mathrm{B}$, the pollen spectrum is still dominated by herb pollens $\mathrm{Ar}$ temisia and Chenopodiaceae. Pollen zone B can be divided into two subzones B1 (72.6 to $66.3 \mathrm{ka} ; 76.34$ to $69.02 \mathrm{~m}$ ) and B2 (66.3 to $61.7 \mathrm{ka}$; 69.02 to $63.49 \mathrm{~m})$.

In subzone B1, the amount of Artemisia and Chenopodiaceae are similar to those of subzone A1. Poaceae and Cyperaceae increase moderately in this zone, the former ranging from 4.6 to $15.7 \%$ (average $8.5 \%$ ) and the latter from 0.5 to $19 \%$ (average 7.3\%). The amount of Picea increases to $22.6 \%$ in the middle part of the zone with a mean of $5.4 \%$. The mount of Pediastrum is still high and fluctuates between 2.0 and $81.3 \%$ (average 16.7\%). The amount of Artemisia slightly decreases in subzone B2, while the amount of Chenopodiaceae increases moderately. The amount of Ephedra decreases moderately with a mean of $2.2 \%$, and the amount of Nitraria rises slightly and exceeds $9 \%$ in the middle of subzone B2, with a mean of 3.0\%. Pediastrum decreases dramatically in subzone B2, and appears in only few samples, that is, less than $1 \%$.

\subsubsection{Pollen zone C (61.7-51.2 ka; 63.49-48.70 m)}

Zone C can be divided into two subzones C1 ( 61.7 to $55.8 \mathrm{ka}$; 63.49 to $55.14 \mathrm{~m}$ ) and C2 (55.8 to $51.2 \mathrm{ka}$; 55.14 to $48.70 \mathrm{~m}$ ). The pollen distribution changes in zone $C$ are the most dramatic of the sequence.

In the subzone C1, Artemisia increases (average 35.2\%) and Chenopodiaceae decreases moderately (average 18.1\%). Poaceae decreases in this zone, ranging from 1 to $10.8 \%$ (average 5.6\%), while the amount of conifer pollen Pinus increases slightly, fluctuating from 0 to $16.7 \%$ (average $4.4 \%$ ). Pediastrum also appears in this subzone, ranging from 0 to $13.4 \%$ (average 3.2\%). The pollen subzone C2 is still dominated by Artemisia and Chenopodiaceae, the former fluctuating between 21.1 and 50\% (average 31.8\%) and the latter from 9.5 to $39.3 \%$ (average 21\%). The amount of Poaceae ranges from 0 to $15.8 \%$ (average $6.1 \%$ ), and Cyperaceae ranges from 1.5 to $10.6 \%$ (average $5.1 \%$ ). Asteraceae increases in this zone and varies from 1.6 to 7.1 (average 4.5\%). The abundance of Pediastrum changes dramatically in this zone as it does not appear in the lower part of subzone C2, swiftly rises to $90.5 \%$ in the upper part of subzone $\mathrm{C} 2$.

\subsubsection{Pollen zone D (51.2-25.3 ka; 48.70-22.46 m)}

Pollen zone D can be divided into two subzones D1 (51.2 to $43 \mathrm{ka}$; 48.70 to $40.77 \mathrm{~m}$ ) and D2 (43 to $25.3 \mathrm{ka} ; 40.77$ to $22.46 \mathrm{~m}$ ). 


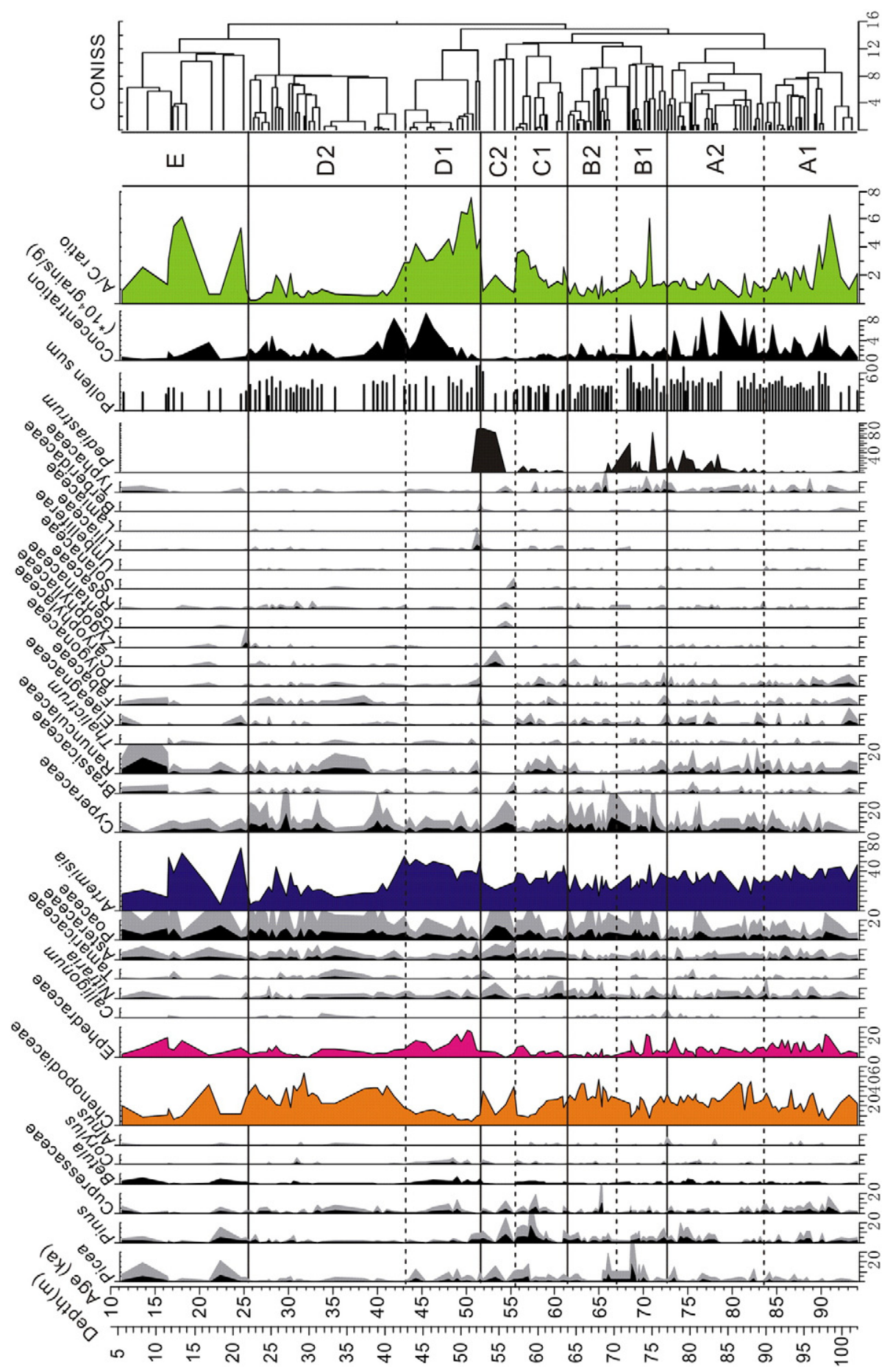

Fig. 3. Pollen percentage diagram from core ISL1A, at Qarhan Lake, Qaidam Basin, NE TP.

Pollen zone D1 is dominated by Artemisia and Halophytic Ephedra. The former varies from 30.7 to $54.7 \%$ (average $44.3 \%$ ) and the latter from 5.5 to $26.6 \%$ (average $16.2 \%$ ). The amount of Chenopodiaceae decreases in this pollen zone, ranging from 4.3 to $18.8 \%$ (average $11.2 \%$ ). The abundance of Cyperaceae decreases markedly in this zone, ranging from 1.2 to $7.4 \%$ (average $3.4 \%$ ), as does Asteraceae, with a mean of $1.7 \%$. Tree taxa are dominated by Betula ( 0.6 to $7.6 \%$; average $2.8 \%$ ), Picea ( 0 to 4.4\%; average $1.7 \%$ ) and Cupressaceae ( 0.4 to $4.4 \%$; average $1.3 \%$ ). Pediastrum, however, has disappeared from this zone. Pollen zone D2 is dominated by Chenopodiaceae and Artemisia, the former fluctuating from 18.3 to $53.4 \%$ (average $32.5 \%$ ) and the latter from 7.0 to $44.1 \%$ (average 22.1\%). The abundance of Ephedra has also declined in this zone, fluctuating between 0 and $11.3 \%$ (average $4.2 \%$ ). In contrast, Poaceae and Cyperaceae increase in this zone, the former varying from 3.8 to $13.4 \%$ (average $8.3 \%$ ) and the latter from 1.3 to $21.4 \%$ (average $6.0 \%$ ). Arboreal pollen was sporadically present in this zone, including Picea, Pinus, Betula and Cupressaceae, with a mean value less than $1 \%$.

\subsubsection{Pollen zone E (25.3-11.3 ka; 22.46-4.32 m)}

Pollen distribution and concentration are unstable in this zone with the amount of Artemisia varying from 7.1 to $58.5 \%$ (average 33.2\%) and the amount of Chenopodiaceae varying from 7.0 to $41.5 \%$ (average 
15.5\%). The abundance of Ephedra is increases moderately, fluctuating between 1.6 and 16.1\% (average 8.5\%). Poaceae and Asteraceae exhibited regular presence with an average of $9.3 \%$ and $2.3 \%$, respectively. The abundance of Cyperaceae decreases in this zone, varying from 0 to $4.7 \%$ (average 3.0\%), while Ranunculaceae reaches its highest value, fluctuating between 0 and $17.4 \%$ (average $4.5 \%$ ). Other sporadically present shrubs and herbs include Nitraria, Tamaricaceae, Ranunculaceae, Fabaceae, Elaeagnaceae, Caryophylaceae and Brassicaceae. The abundance of arboreal pollen increases slightly in this zone with Picea ranging from 0 to 7.1 (average 1.8\%), Pinus ranging from 0 to 5.2\% (average $1.1 \%$ ) and Betula ranging from 0 to $5.2 \%$ (average 1.3\%).

\section{Discussion}

\subsection{Proxy interpretation}

The Artemisia/Chenopodiaceae $(\mathrm{A} / \mathrm{C})$ ratio has been commonly used as an indicator of effective moisture in arid and semi-arid regions where Artemisia and Chenopodiaceae are the dominant plants (El-Moslinmny, 1990; Liu et al., 1999; Tarasov et al., 1999; Zheng et al., 2008; Zhao et al., 2012b), as Artemisia requires more water than Chenopodiaceae during the growing season. Previous studies suggest that the $\mathrm{A} / \mathrm{C}$ ratio can be used to distinguish the vegetation types in the regions of steppes, steppe deserts and deserts (Liu et al., 1999; Herzschuh et al., 2003; Luo et al., 2010; Zhao et al., 2012a). Our previous studies with respect to the northeastern TP have further demonstrated a positive relationship between the $\mathrm{A} / \mathrm{C}$ ratio and mean annual precipitation (Zhao et al., 2008; Wei et al., 2011). However, soil salinity, pollen productivity and transportation, vegetation community composition and sample provenance (e.g., soil and lake sediments) affect the values of the $\mathrm{A} / \mathrm{C}$ ratio in different vegetation zones (Zhao et al., 2012b). Thus, these factors may affect the reliability of the application of the $\mathrm{A} / \mathrm{C}$ ratio in reconstructing vegetation and climate from lake cores. The Qarhan Salt Lake is a large enclosed lake, with many inflow rivers originating from the surrounding high mountains pouring into the lake. These inflow rivers carry many pollen grains from surrounding mountains and intrazonal plant communities into the lake. Therefore, the $\mathrm{A} / \mathrm{C}$ ratio from lake cores may underestimate the degree of desertification because of the amount of Artemisia pollen from intrazonal plant communities being transported by water to the lake, which further complicates the understanding of the $\mathrm{A} / \mathrm{C}$ ratio. Accordingly, attention should be paid to those situations when reconstructing the paleo-vegetation change of the Qaidam Basin.

Pediastrum, which belongs to the Chlorophyceae green algae, has been associated with the different latitudes of lake sediments throughout the world. Paleoenvironmental interpretations from records of Pediastrum in lake sediments are not straight forward as previous studies are interpreted as reflecting changes in temperatures and the nutritional status of the freshwater lakes (Rull et al., 2008; Mackay et al., 2013), fluctuations in water levels (Sylvestre, 2002; Chepstow-Lusty et al., 2005; Jiang et al., 2006; Sarmaja-Korjonen et al., 2006; Zhao et al., 2007; Gosling et al., 2008; Whitney and Mayle, 2012), as well as links to levels of $\mathrm{pH}$ and DOC (Weckström et al., 2010). As the Pediastrum genus contains many species of diverse ecological affiliations, its abundance in sediments reflects a variety of aquatic conditions (Whitney and Mayle, 2012). However, it has been confirmed that Pediastrum currently prefers fresh or brackish water, and it, has not adapted to hyper-saline water conditions. Furthermore, it has been demonstrated that Pediastrum colonies increase with water depth in lakes of the northeastern Qaidam Basin (Zhao et al., 2007), and the survival depth of Pediastrum is considered to be no more than $15 \mathrm{~m}$ (Zheng et al., 2003; Zhang et al., 2004). Given that Pediastrum communities are found to vary among different lake habitats (Danielsen, 2010; Kaufman et al., 2010), we speculate that an increase in the salinity of the lake indicates a shrinking of the lake water body and a low lake level. In contrast, a decrease in salinity indicates a relatively high lake level. Thus, the salinity associated with lake level change of the Qarhan paleolake during the Late Pleistocene may be qualitatively inferred from the varying concentrations of Pediastrum. The alternations in lithostratigraphy provide a robust signal regarding the core that indicates a consistent whole-basin response to climate change. Halite was deposited during lake lowstands (i.e., dry climate), whereas clay-rich sediments were deposited during lake highstands (i.e., wet climate) when runoff and detrital input to the lake were relatively high. The increase of the clay content in the core sediment indicates an increase in precipitation and runoff, while, in contrast, the halite deposit layers indicate an arid climate. Thus, alternations between halite and clay deposition reflect dry-wet climate change cycles in the Basin.

\subsection{Lithology-inferred climate}

In the interval from 94 to $53.2 \mathrm{ka}$ (102 to $51.59 \mathrm{~m}$ ), the core sediment consisted of organic-rich silty clay. This suggests that conditions were relatively moist during the late MIS 5, 4, and early MIS 3. The first layer of gypsum and halite occurred at 53.2 to $52.1 \mathrm{ka}$ ( 51.59 to $49.93 \mathrm{~m}$ ) and may have been deposited at the same time as the Heinrich event 5 (Broecker et al., 1992; Guo et al., 1996), although the resolution of the ISL1A chronology model is low and there is high dating uncertainty in this interval. The onset of evaporate during this period signifies lowstand of the lake and relatively dry conditions in the basin. The Qaidam Basin experienced rapid climate changes between 50.2 and $32.5 \mathrm{ka}$ (47.36 to $31.57 \mathrm{~m}$ ) as marked by the millennial-scale oscillations in halite and clay deposition. Clay-rich sediments deposited between 32.5 and $25.3 \mathrm{ka}$ (31.57 to $22.46 \mathrm{~m}$ ) suggests an increase in runoff of the lake under relatively wet climatic conditions. The amount of halite deposited in the core sediment since $25.3 \mathrm{ka}$ indicates that the lake level decreased significantly in volume and saline compared to previous periods of the Late Pleistocene. And very arid conditions occurred in Qarhan Salt Lake during MIS2. However, Lithological sequences from Chaka Salt Lake of eastern edge of Qaidam Basin indicate that a clastic-dominated, freshwater lake was developed between 17.2 and 11.4 cal ka BP (Liu et al., 2008). A possible interpretation for this discrepancy is that evaporation caused by warmer temperature in Qarhan Salt Lake may have been sufficient to balance the quantity of melting glacial water and the precipitation, but it may have not been sufficient in Chaka Salt Lake.

\subsection{Pollen inferred vegetation history and evolution of Qarhan paleolake}

We use the pollen distributions in the ISL1A core to infer the vegetation, environment and paleolake level changes of the Qarhan Salt Lake during the Late Pleistocene. In the pollen record, Artemisia and Chenopodiaceae were the most abundant taxa, though Ephedra, Poaceae, Cyperaceae, Asteraceae, Nitraria, Polygonaceae, Ranunculaceae and Fabaceae were also important components. The main problem in the use of the pollen data in paleo-vegetation and paleo-climate studies is defining the pollen representation and its provenance. Previous studies indicate that pollen grains of lake sediment are originated from whole drainage basin vegetation and that the local vegetation around the lake can, to a certain extent, influence the distribution of pollen in the lake (Xu et al., 2005; Shang et al., 2009). The Qarhan Salt Lake is a large enclosed lake that has many inflowing rivers, which combined with high winds common to the area, further complicates the interpretation of the fossil pollen of the core sediments. Previous studies (Herzschuh et al., 2010; Wei et al., 2011) of the northeastern TP show that in the temperate steppe zone, pollen spectra are dominated by $\mathrm{Ar}$ temisia and Chenopodiaceae along with an abundance of Poaceae, Fabaceae and Asteraceae. In the desert zone, Chenopodiaceae and Ephedra dominate the pollen spectra, while there are relatively low percentages of Artemisia. However, Nitraria and Calligonum are also frequently present in the pollen spectra. Cyperaceae and Poaceae are typically found in moister environments or around lakes (Sun et al., 2003; Shang et al., 2009). Artemisia, Chenopodiaceae and Ephedra have a high representation value, are strong pollen producers and have 
effective dispersal mechanisms, while Cyperaceae exhibits moderate relative representation ratios compared with Poaceae (Wei et al., 2011). Most previous studies indicate that percentages of Poaceae in arid and semi-arid China are normally $<10 \%$ and are underrepresented (Liu et al., 1999; Li et al., 2005). Other pollen taxa, including Asteraceae, Polygonaceae, Ranunculaceae, Fabaceae and Rosaceae, occurring in alpine meadows and temperate steppes, are also underrepresented. Accordingly, it is concluded that the representativeness and provenance of the pollen taxa should be carefully considered.

\subsubsection{4 to $51.2 \mathrm{ka}$ (late MIS 5, 4, and early MIS 3)}

During the late MIS5 ( 94 to $72.6 \mathrm{ka}$ ), the steppe vegetation dominated by Artemisia, Poaceae and Chenopodiaceae developed around the lake, and Ephedra shrub probably occurred in the foothills of the south-central Kunlun Mountain. Pediastrum was frequently present during this period, indicating relatively high lake levels and low values of salinity with respect to the lake in a relatively warm and wet climate. Interestingly, Chenopodiaceae, usually found in arid or salty-rich environments, shows a remarkable increase in abundance between 84.2 and $80.6 \mathrm{ka}$, suggesting that a Chenopodiaceae dominated steppe desert developed around the lake, which coincided with a dry climate in the Qaidam Basin.

During early MIS 4 ( 72.6 to $66.3 \mathrm{ka}$ ), the vegetation consisted of Artemisia dominated steppe. The amount of Poaceae and Cyperaceae increased moderately, and Pediastrum proliferated during this period, suggesting lower levels of salinity and relatively higher lake levels. Meanwhile, Picea, which typically found in wet and cool climate, commonly occurring at the elevations from 2500 to $4000 \mathrm{~m}$ a.s.l., mean annual temperature (MAT) from -1 to $10{ }^{\circ} \mathrm{C}$ and MAP from 450 to $850 \mathrm{~mm}$, reached its highest values (22.5\%) (Lu et al., 2004, 2008). The conditions further indicate that the spruce forest likely occurred in the nearby mountains. Accordingly, the pollen composition during this period was slightly different from that of the late MIS5, thus suggesting slight differences in climatic conditions between these two periods, with a cool, wetter climatic condition dominating during this period.

Vegetation and climate changed dramatically between 66.3 and $61.7 \mathrm{ka}$ as the steppe desert vegetation dominated by Chenopodiaceae and Artemisia developed in the central eastern Qaidam Basin, while Pediastrum disappeared during this period. These events suggest a relatively high level of salinity in the lake and low lake levels due to a relatively cold, dry climate. Steppe vegetation dominated by Artemisia, Chenopodiaceae and Poaceae occurred again during the late MIS 4 and early MIS 3 (61.7 to $51.2 \mathrm{ka}$ ). Patches of deciduous forest dominated by Betula and Poplus probably occurred in the mountain valleys of the basin during this period, while Pediastrum was also continuously present during this time, thus indicating a relatively low level of salinity and higher lake levels.

\subsection{2. $51.2-25.3 \mathrm{ka}$}

The middle MIS3 is marked by the expansion of Artemisia and Ephedra dominated vegetation and the disappearance of Pediastrum in the core sediment. This coincides with a salt-bearing deposit in the core, which suggests lowstand of the lake and relatively dry climate conditions in the basin since $51.2 \mathrm{ka}$. A pollen assemblage of Artemisia and Ephedra is rarely found in modern samples of TP because the ecological habits of Artemisia and Ephedra are different. Artemisia is dominant in temperate steppe zones in northern China, while Ephedra frequently appears in arid and semiarid areas of northwestern China and the Qaidam Basin (Li et al., 2005; Zhao and Herzschuh, 2009; Wei et al., 2011). In this stage, high values of Artemisia pollen probably ascribed to dry climate conditions led to lower lake levels and riverbed exposure, which are suitable habitats for the colonization of an Artemisia dominated community. The rivers then transported the Artemisia pollen to the lake. The expansion of an Ephedra shrub-steppe during the glacial stage was also recorded in Lake Urmia, NW Iran, and the analog of Ephedra and Artemisia dominated vegetation type in the present was reported from the foothills of Iran in an arid area (Djamali et al., 2008). Thus, herein we infer that the relatively dry climate at that time led to increased evaporation and a drop in effective humidity, thus promoting the development of Ephedra because the drop in the lake level led to a low water table in the basin. Ephedra dominated shrub-desert vegetation developed in the foothills around the lake during the middle MIS3 (51.2 to $43 \mathrm{ka}$ ), while Chenopodiaceae dominant desert vegetation began to appear around the lake as early as $43 \mathrm{ka}$. The increase in Chenopodiaceae may, therefore, reflect lower lake levels and the resultant extension of suitable habitats for the colonization of halophilous Chenopodiaceae. Nevertheless, the climate improved between 32.5 and $25.3 \mathrm{ka}$, and Artemisia was the dominant desert steppe vegetation growing in the vicinity of the lake. The deposition of an organic-rich silty clay corresponded with the higher $\mathrm{A} / \mathrm{C}$ ratio in the core sediments, thus suggesting higher lake levels, which then diluted the water body from a hyper-saline concentration to a brackish concentration. However, it is further noted that the range of lake expansion was limited during this stage.

\subsubsection{3-11.3 ka (Late-glacial)}

A detailed picture of late glacial vegetation dynamics cannot be given herein because of the low resolution of this stage. However, a decline in pollen concentration is likely a signal of a cold, dry climatic condition during this stage. Desert vegetation dominated by Chenopodiaceae and Ephedra probably developed in the basin, and relatively high percentages of Artemisia, likely due to seasonal river flows, transported the Artemisia pollen from the riverbeds to the lake. This corresponded with the deposition of the amount of halite in the core sediment. At the same time, a lower input of terrigenous siliciclastic sediments was the result of the drying up of the streams, and accordingly, the Qarhan Salt Lake finally evolved into a dry playa by the end of MIS2.

\subsection{Regional correlation and possible mechanism}

In order to better understand Qarhan Salt Lake evolution and its response to regional and global climatic changes, we made a comparison between the pollen record of Qarhan Salt Lake and other paleoclimatic proxy records in the TP, as well as regional and global climate changes (Fig. 4). During the interglacial MIS5 and inter-stadials MIS3c and MIS3a, Artemisia dominated steppe vegetation developed in the central eastern basin. Meanwhile, Pediastrum also appeared continually during the late MIS5 and MIS3c in the core sediment, indicating a relatively wetter climate and high lake level. Clay-rich sediments were deposited during MIS5, MIS3c and MIS3a in the core sediment, which also reflected an increase in precipitation and runoff in the Basin. This conclusion has been verified by geomorphic and chronometric evidence at Gahai, Toson and Qinghai Lakes on the NE TP. Geomorphic and optically stimulated luminescence (OSL) ages demonstrate that higher lake level periods of the Gahai Lake occurred at 85 to 72 and 63 to $55 \mathrm{ka}$, which correspond to late MIS 5 and early MIS 3 (Fan et al., 2010, 2012). Meanwhile, a high lake level of Toson Lake during MIS3 was recorded at $31 \mathrm{ka}$ (Fan et al., 2012). Furthermore, a large number of high paleo-shorelines have been identified along the southern margin of Qinghai Lake, and OSL dating results suggest that high lake levels that are $\sim 20$ to $66 \mathrm{~m}$ above that of the modern lake occurred at 110-75 ka (Madsen et al., 2008; Liu et al., 2010; Rhode et al., 2010). Pollen record from Zoige Basin of eastern Tibetan Plateau indicate that coniferous forest expanded in the catchment of the Zoige Basin during last interglacial and some periods of last glacial (Chen et al., 1999). Paleoclimatic proxy records from ice-cores, stalagmites and Chinese loess during the late Pleistocene also allow us to speculate on the causes and teleconnections of global climate changes (Fig. 4). The $\delta^{18} \mathrm{O}$ curve of the Guliya ice-core (Thompson et al., 1997) from the west Kunlun Mountains on the northern margin of the TP indicates that higher regional temperatures were recorded during MIS5, MIS3c and MIS3a. These climate changes are consistent with 


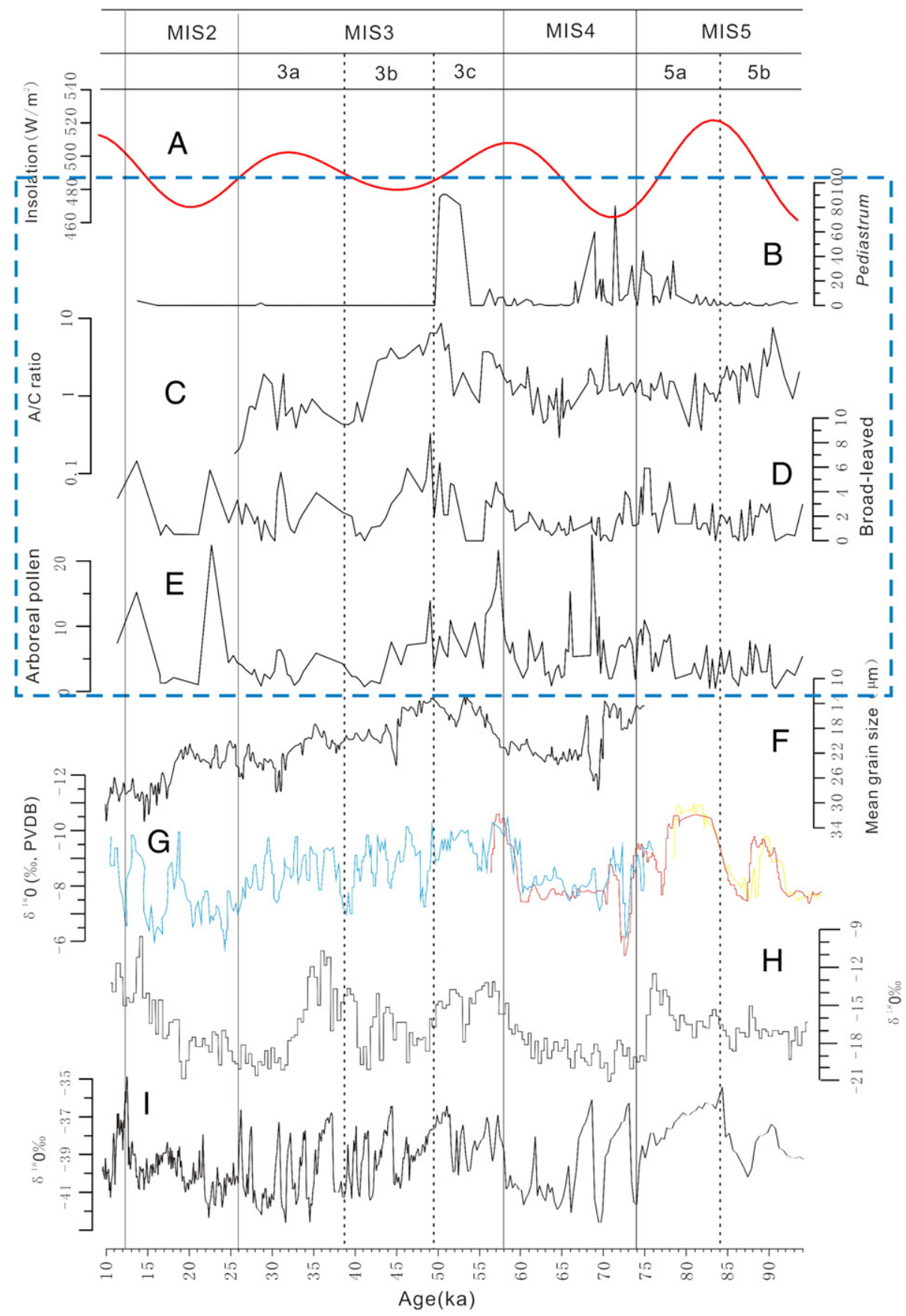

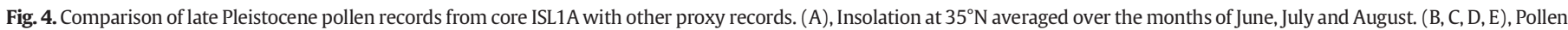

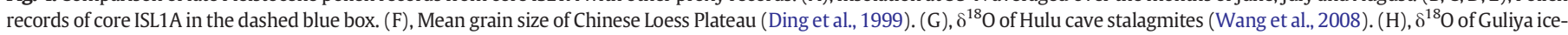
core (Thompson et al., 1997). (I), $\delta^{18} \mathrm{O}$ of Greenland ice-core (Stuiver and Grootes, 2000).

glacial cycles recorded in Northern Hemisphere ice-cores (Stuiver and Grootes, 2000). In addition, loess archives provided similar evidence, such as fine grain sizes accumulated during MIS5, MIS3c and MIS3a (Ding et al., 1999), thus, implying a strengthening in intensity of the Asian summer monsoon (ASM) and a declining winter monsoon circulation. It was also confirmed by $\delta^{18} \mathrm{O}$ of stalagmites recorded in the East Asian area (Wang et al., 2001, 2008). The Qarhan Salt Lake is located in the eastern Qaidam Basin of the NE TP, just beyond the northern limit of the modern ASM influence (Winkler and Wang, 1993). In this study, while we cannot confirm that the front of intensified ASM westward penetration brought some precipitation to the southeastern edge of lake catchments of Qarhan paleolake during the last interglacial, reconstructed climate record indicate that there was high humidity in central eastern Qaidam Basin during these stages. These same conditions were also present in Qinghai Lake, which is near Qaidam Basin. Accordingly, more climate records are needed to identify the causes of the climate changes during the last interglacial in the basin.

Climate and lake level during early MIS4 differ little from other records, as a relatively high percentage of Artemisia, Picea and Pediastrum suggest cool and relatively wet climatic conditions and high lake levels. This may be related to the relatively high precipitation and low evaporation rates during this period. During late MIS4, Pediastrum disappeared and the $\mathrm{A} / \mathrm{C}$ ratio decreased in the core sediment, indicating a colder, dryer climate in the central eastern Qaidam Basin. Chenopodiaceae dominated the desert steppe developed around the lake during this stage. The GISP2 $\delta^{18} \mathrm{O}$ value decreased with small 
fluctuations during late MIS4, implying decreasing temperatures (Stuiver and Grootes, 2000). A cold, dry climate is also suggested by a loess deposition in Chinese loess sections during this period (Guo et al., 1996). The extinction of Pediastrum and expansion of Ephedrashrub desert occurred simultaneously with halite bearing deposits in the core sediments during MIS3b, indicating a dry climatic condition. This result was confirmed by the ostracode assemblages of a Luanhaizi Lake core from the Qilian Mountains, which indicated cold and dry conditions prevailed and a thick sequence of playa deposits accumulated after $45 \mathrm{ka}$ (Mischke et al., 2005). The pollen record from Lanzhou also indicates that arboreal pollen decreased significantly in abundance at 46.0-39.0 ka (Jiang et al., 2011). A cold, dry climate was also recorded during MIS2 based on the decline of pollen concentration and the deposition of halite in the core sediment. Previous studies on Pleistocene glaciers demonstrated that a Late Pleistocene glacier in northeastern TP advanced during MIS3b and MIS2 (Owen et al., 2003; Owen et al., 2006; Ou et al., 2014). Meanwhile, the mean moisture values decrease noticeably in central Asia after 2.7 ka BP (Herzschuh, 2006). From MIS 3 to MIS 2, a climate decline can be observed with the gradual coarsening of eolian grain size (Chen et al., 1997). The $\delta^{18}$ O value of Hulu stalagmites also indicate a decreasing moisture trend during MIS3b and MIS2 under lower NHSI (Wang et al., 2008). The pollen record from the East China Sea show that subtropical trees were notably fewer during the Last Glacial Maximum (LGM) and the terminal period of MIS 3, suggesting a colder, dryer climate (Zheng et al., 2011). During the last glaciation, the ASM was weak and Westerlies were dominant on Qinghai Lake in NE TP (An et al., 2012). Thus, the weak NHSI account for cold and dry climatic conditions in the study area during glacial stages.

\section{Conclusions}

The pollen diagrams from Qarhan Salt Lake are the longest record of past vegetation from the central eastern Qaidam Basin in NE TP. During the late MIS5, early MIS4 and early MIS3, organic-rich clay lacustrine deposits and the frequently presence of Pediastrum reveal that the Qarhan paleolake had a relatively high lake level and oligohaline water conditions. Artemisia and Chenopodiaceae dominated steppe vegetation developed around the lake, thus indicating a warmer and wetter climate. During late MIS4, Chenopodiaceae dominated the desert steppe developed around the lake, and Pediastrum disappeared in the core sediment, reflecting dryer climatic conditions and a low lake level. Ephedra-shrub desert developed during middle MIS3, which coincided with the disappearance of Pediastrum and the salt-bearing deposit in the core sediment, reflecting dryer climatic conditions. The predominance of Chenopodiaceae in the halophytic communities occurred around the lake since $43 \mathrm{ka}$. However, the climate was much less sever between 32.5 and $25.3 \mathrm{ka}$, as inferred from the clay-rich sediment deposition in the core sediment while Artemisia dominated the desert steppe vegetation developed around the lake. Pollen concentrations obviously declined since $25.3 \mathrm{ka}$, based on the amount of halite deposited in the core sediment, thus suggesting cold and dry climatic conditions in the Qaidam Basin. A regional correlation between the pollen record of the core ISL1A and other climate records suggest that runoff and effective humidity increased under higher NHSI during the late MIS5, MIS3c and MIS3a, while weak NHSI accounts for cold and dry climatic conditions during the glacial stages in the study area.

\section{Acknowledgments}

This work was financially supported by the National Natural Science Foundation of China (Grants \# 41301045; \# 41302024). We are grateful to the Editor and two anonymous reviewers for their helpful comments and suggestions to improve the manuscript.

\section{Appendix A. Supplementary data}

Supplementary data associated with this article can be found in the online version, at http://dx.doi.org/10.1016/j.palaeo.2015.04.025. These data include Google map of the most important areas described in this article

\section{References}

An, Z.S., Colman, S.M., Zhou, W.J., et al., 2012. Interplay between the Westerlies and Asian monsoon recorded in Lake Qinghai sediments since 32 ka. Sci. Rep. 2 (619), 1-7.

Broecker, W., Bond, G., Klas, M., Clark, E., McManus, J., 1992. Origin of the northern Atlantic's Heinrich events. Clim. Dyn. 6, 265-273.

Chen, K.Z., Bowler, J.M., 1985. Preliminary study of sedimentary characteristics and evolution of palaeoclimate of Qarhan Salt Lake in Qaidam Basin. Sci. Sin. Ser. B 28, 1218-1232.

Chen, K.Z., Bowler, J.M., 1986. Late Pleistocene evolution of salt lakes in the Qaidam Basin, Qinghai Province, China. Palaeogeogr. Palaeoclimatol. Palaeoecol. 54, 87-104.

Chen, KZ Bowler, J.M., Kelts, K, 1990. Palaeoclimatic evolution within the Qinghai-Xizang Plateau in the last 40000 years. Quat. Sci. 1, 21-31 (In Chinese with English abstract).

Chen, F.H., Bloemendal, J., Wang, J.M., Li, J.J., Oldfield, F., 1997. High-resolution multiproxy climate records from Chinese Loess: evidence for rapid climatic changes over the last 75 kyr. Palaeogeogr. Palaeoclimatol. Palaeoecol. 130, 323-335.

Chen, F.H., Bloemendal, J., Zhang, P.Z., Liu, G.X., 1999. An 800 ky proxy record of climate from lake sediments of the Zoige Basin, the eastern Tibetan Plateau. Palaeogeogr. Palaeoclimatol. Palaeoecol. 151 (4), 307-320.

Chepstow-Lusty, A., Bush, M.B., Frogley, M.R., Baker, P.A., Fritz, S.C., Aronson, J., 2005. Vegetation and climate change on the Bolivian Altiplano between 108,000 and 18,000 yr ago. Quat. Res. 63, 90-98.

Danielsen, R., 2010. Dissimilarities in the recent histories of two lakes in Portugal explained by local scale environmental processes. J. Paleolimnol. 43, 513-534.

Ding, Z.L., Sun, J.M., Rutter, N.W., Rokosh, D., Liu, T.S., 1999. Changes in sand content of loess deposits along a north-south transect of the Chinese Loess Plateau and the implications for desert variations. Quat. Res. 52, 56-62.

Djamali, M., Beaulieu, J.L., Shah-hosseini, M., Andrieu-Ponel, V., Ponel, P., Amini, A., Akhani, H., Leroy, S., Stevens, L., Lahijani, H., Brewer, S., 2008. A late Pleistocene long pollen record from Lake Urmia, NW Iran. Quat. Res. 69, 413-420.

El-Moslinmny, A., 1990. The ecological significance of common nonarboreal pollen: example from dryland of the Middle East. Rev. Palaeobot. Palynol. 64, 343-350.

Fan, Q.S., Lai, Z.P., Long, H., Sun, Y.J., Liu, X.J., 2010. OSL chronology for lacustrine sediments recording high stands of Gahai Lake in Qaidam Basin, northeastern Qinghai-Tibetan Plateau. Quat. Geochronol. 5, 223-227.

Fan, Q.S., Ma, H.Z., Cao, G.C., Chen, Z.Y., Cao, S.K., 2012. Geomorphic and chronometric evidences for high lake level history in Gahai Lake and Toson Lake of northeastern Qaidam Basin, northeastern Qinghai-Tibetan Plateau. J. Quat. Sci. 27 (8), 819-827.

Fan, Q.S., Ma, H.Z., Wei, H.C., Shan, F.S., An, F.Y., Xu, L.M., Madsen, D.B., 2014a. Late Pleistocene paleoclimatic history documented by an oxygen isotope record from carbonate sediments in Qarhan Salt Lake, NE Qinghai-Tibetan Plateau. J. Asian Earth Sci. 85, 202-209.

Fan, Q.S., Ma, H.Z., Ma, Z.B., Wei, H.C., Han, F.Q., 2014b. An assessment and comparison of ${ }^{230} \mathrm{Th}$ and AMS ${ }^{14} \mathrm{C}$ ages for lacustrine sediments from Qarhan Salt Lake area in arid western China. Environ. Earth Sci. 71 (3), 1227-1237.

Gosling, W.D., Bush, M.B., Hanselman, J.A., Chepstow-Lusty, A., 2008. Glacial-interglacial changes in moisture balance and the impact on vegetation in the Southern Hemisphere tropical Andes (Bolivia/Peru). Palaeogeogr. Palaeoclimatol. Palaeoecol. 259, $35-50$.

Grimm, E.C., 1987. CONISS: a Fortran 77 program for stratigraphically constrained cluster analysis by the method of incremental sum of squares. Comput. Geosci. 13, 13-35.

Guo, Z.T., Liu, T.S., Guiot, J., Wu, N.Q., Lu, H.Y., Han, J.M., Liu, J., Gu, Z.Y., 1996. High frequency pulses of East Asian monsoon climate in the last two glaciations: link with the North Atlantic. Clim. Dyn. 12, 701-709.

Herzschuh, U., 2006. Palaeo-moisture evolution in monsoonal Central Asia during the last 50,000 years. Quat. Sci. Rev. 25, 163-178.

Herzschuh, U., Kürschner, H., Ma, Y.Z., 2003. The surface pollen and relative pollen production of the desert vegetation of the Alashan Plateau, western Inner Mongolia. Chin. Sci. Bull. 48 (14), 1488-1493.

Herzschuh, U., Birks, H.J.B., Mischke, S., Zhang, C.J., Böhner, J., 2010. A modern pollenclimate calibration set based on lake sediments from the Tibetan Plateau and its application to a Late-Quaternary pollen record from the Qilian Mountains. J. Biogeogr. 37, 752-766

Hou, H., 2001. Vegetation Atlas of China. Science Press China: Science Press, Beijing, pp. 20-80.

Huang, Q., Chen, K.Z., 1990. Palaeoclimatic fluctuation fashion of Qarhan Salt Lake in Qaidam Basin in the past 730,000 years. Quat. Sci. 3, 205-212 (in Chinese)

Jiang W.Y, Guo, ZT, Sun, X.J., Wu, H.B., Chu, G.Q, Yuan, B.Y, Hatte, C, Guiot, J., 2006. Reconstruction of climate and vegetation changes of Lake Bayanchagan (Inner Mongolia): Holocene variability of the East Asian monsoon. Quat. Res. 65, 411-420.

Jiang, H.C., Mao, X., Xu, H.Y., Thompson, J., Wang, P., Ma, X.L., 2011. Last glacial pollen record from Lanzhou (Northwestern China) and possible forcing mechanisms for the MIS 3 climate change in Middle to East Asia. Quat. Sci. Rev. 30, 769-781.

Kaufman, D.S., Anderson, R.S., Hu, F.S., Berg, E., Werner, A., 2010. Evidence for a variable and wet younger dryas in southern Alaska. Quat. Sci. Rev. 29, 1445-1452. 
Lai, Z.P., Mischke, S., Madsen, D., 2014. Paleoenvironmental implications of new OSL dates on the formation of the "Shell Bar" in the Qaidam Basin, northeastern QinghaiTibetan Plateau. J. Paleolimnol. 51, 197-210.

Li, Y.C., Xu, Q.H., Zhao, Y.K., Yang, X.L., Xiao, J.L., Chen, H., Lu, X.M., 2005. Pollen indication to source plants in the eastern desert of China. Chin. Sci. Bull. 50, 1632-1641.

Liu, Z.C., Wang, Y.J., Chen, Y., Li, X.S., Li, Q.C., 1998. Magnetostratigraphy and sedimentologically derived geochronology of the Quaternary lacustrine deposits of a $3000 \mathrm{~m}$ thick sequence in the central Qaidam Basin, Western China. Palaeogeogr. Palaeoclimatol. Palaeoecol. 140, 459-473.

Liu, H.Y., Cui, H.T., Pott, R., 1999. The surface pollen of the woodland-steppe ecotone in southeastern Inner Mongolia, China. Rev. Palaeobot. Palynol. 105, 237-250.

Liu, X.Q., Dong, H.L., Rech, J.A., Matsumoto, R., Yang, B., Wang, Y.B., 2008. Evolution of Chaka Salt Lake in NW China in response to climatic change during the Latest Pleistocene-Holocene. Quat. Sci. Rev. 27, 867-879.

Liu, X.J., Lai, Z.P., Fan, Q.S., Long, H., Sun, Y.J., 2010. Timing for high lake levels of Qinghai Lake in the Qinghai-Tibetan Plateau since the last interglaciation based on quartz OSL dating. Quat. Geochronol. 5, 218-222.

Lu, H.Y., Wang, S.Y., Shen, C.M., Yang, X.D., Tong, G.B., Liu, K.B., 2004. Spatial pattern of modern Abies and Picea pollen in the Qinghai-Xizang Plateau. Quat. Sci. 24, 39-49 (in Chinese).

Lu, H.Y., Wu, N.Q., Yang, X.D., Shen, C.M., Zhu, L.P., Wang, L., Li, Q., Xu, D.K., Tong, G.B., Sun, X.J., 2008. Spatial pattern of Abies and Picea pollen distribution along the elevation gradient in the Qinghai-Tibetan Plateau and Xinjiang, China. Boreas 37, 254-262.

Ludwig, K.R., 1991. ISOLOPT a plotting and regression program for radiogenic-isotope data. U.S. Geological Survey Open-File Report 91-445p. 41

Luo, C.X., Zheng, Z., Tarasov, P., Nakagawa, T., Pan, A.D., Xu, Q.H., Lu, H.Y., Huang, K.Y. 2010. A potential of pollen-based climate reconstruction using a modern pollenclimate dataset from arid northern and western China. Rev. Palaeobot. Palynol. $160,111-125$.

Ma, Z.B., Wang, Z.H., Liu, J.Q., Yuan, B.Y., Xiao, J.L., Zhang, G.P., 2004. U-series chronology of sediments associated with Late Quaternary fluctuations, Blikun Lake, northwest China. Quat. Int. 121, 89-98.

Ma, Z.B., Zheng, M.P., Wu, Z.H., Ma, N.N., 2010a. U-Th isochron dating of impure carbonates and the possible effect of isotopic fractionation during leaching. Acta Geol. Sin. 84 (8), 1146-1153 (in Chinese with English abstract).

Ma, Z.B., Ma, N.N., Zhang, X.F., Wang, Y., 2010b. ${ }^{230} \mathrm{Th} / \mathrm{U}$ chronology of late Pleistocene lacustrine deposits in Zhabuye Salt Lake, Tibetan Plateau. Acta Geol. Sin. 84 (11), 1641-1651 (in Chinese with English abstract).

Mackay, A.W., Bezrukova, E.V., Boyle, J.F., Holmes, J.A., Panizzo, V.N., Piotrowska, N., Shchetnikov, A., Shilland, E.M., Tarasov, P., White, D., 2013. Multiproxy evidence for abrupt climate change impacts on terrestrial and freshwater ecosystems in the Ol'khon region of Lake Baikal, central Asia. Quat. Int. 290-291, 46-56.

Madsen, D.B., Ma, H.Z., Rhode, D., Brantingham, P.J., Forman, S.L., 2008. Age constraints on the late Quaternary evolution of Qinghai Lake, Tibetan Plateau. Quat. Res. 69, 316-325.

Madsen, D., Lai, Z.P., Sun, Y.J., Rhode, D., Liu, X.J., Brantingham, P.J., 2014. Late Quaternary Qaidam lake histories and implications for an MIS 3 "Greatest Lakes" period in northwest China. J. Paleolimnol. 51, 161-177.

Mischke, S., Herzschuh, U., Zhang, C., Bloemendal, J., Riedel, F., 2005. A Late Quaternary lake record from the Qilian Mountains (NW China): lake level and salinity changes inferred from sediment properties and ostracod assemblages. Glob. Planet. Chang. 46, 337-359

Mischke, S., Lai, Z.P., Zhang, C.J., 2014. Re-assessment of its palaeoclimatic implications of the Shell Bar in the Qaidam Basin, China. J. Paleolimnol. 51, 179-195.

Moore, P.D., Webb, J.A., Collinson, M.E., 1991. Pollen Analysis. 2nd ed. Blackwell Scientific Publications, Oxford.

Ou, X.J., Lai, Z.P., Zhou, S.Z., Zeng, L.H., 2014. Timing of glacier fluctuations and trigger mechanisms in eastern Qinghai-Tibetan Plateau during the Late Quaternary. Quat. Res. 81, 464-475.

Owen, L.A., Finkel, R.C., Haizhou, M., Spencer, J.Q., Derbyshire, E., Barnard, P.L., Caffee, M.W., 2003. Timing and style of Late Quaternary glaciation in northeastern Tibet. Geol. Soc. Am. Bull. 115, 1356-1364.

Owen, L.A., Finkel, R.C., Ma, H.Z., Barnard, P.L., 2006. Late Quaternary landscape evolution in the Kunlun Mountains and Qaidam Basin, Northern Tibet: a framework for examining the links between glaciation, lake level changes and alluvial fan formation. Quat. Int. 154-155, 73-86.

Rhode, D., Ma, H.Z., Madsen, D.B., Brantingham, P.J., Forman, S.L., Olsen, J.W., 2010. Paleoenvironmental and archaeological investigations at Qinghai Lake, western China: geomorphic and chronometric evidence of lake level history. Quat. Int. 218, 29-44.

Rull, V., Lopez-Saez, J.A., Vegas-Vilarrubia, T., 2008. Contribution of non-pollen palynomorphs to the paleolimnological study of a high-altitude Andean lake (Laguna Verde Alta, Venezuela). J. Paleolimnol. 40, 399-411.

Sarmaja-Korjonen, K., Seppänen, A., Bennike, O., 2006. Pediastrum algae from the classic late glacial Bølling Sø site, Denmark: response of aquatic biota to climate change. Rev. Palaeobot. Palynol. 138, 95-107.

Shang, X., Li, X.Q., An, Z.S., Ji, M., Zhang, H.B., 2009. Surface pollen analysis in Qinghai Lake Basin. Sci. China Ser. D 39 (9), 1288-1296.

Stuiver, M., Grootes, P.M., 2000. GISP2 oxygen isotope ratios. Quat. Res. 53, 277-284.
Sun, X.J., Luo, Y.L., Huang, F., Tian, J., Wang, P.X., 2003. Deep-sea pollen from the South China Sea: Pleistocene indicators of East Asian monsoon. Mar. Geol. 201, 97-118.

Sylvestre, F., 2002. A high-resolution diatom reconstruction between 21,000 and $17,400{ }^{14} \mathrm{C}$ yr BP from the southern Bolivian Altiplano (18-23으. J. Paleolimnol. 27, 45-57.

Tarasov, P.E., Guiot, J., Cheddadi, R., Andreev, A.A., Bezusko, L.G., Blyakharchuk, T.A. Dorofeyuk, N.I., Filimonova, L.V., Volkova, V.S., Zernitskaya, V.P., 1999. Climate in northern Eurasia 6000 years ago reconstructed from pollen data. Earth Planet. Sci. Lett. 171, 635-645.

Thompson, L.G., Yao, T.D., Davis, M.E., Henderson, K.A., Mosley-Thompson, E., Lin, P.N. Beer, J., Synal, H.A., Cole-Dai, J., Bolzan, J.F., 1997. Tropical climate instability: the last glacial cycle from a Qinghai-Tibetan ice core. Science 276, 1821-1825.

Wang, F.X., Qian, N.F., Zhang, Y.L., 1995. Pollen Flora of China. Science Press, Beijing (in Chinese).

Wang, Y.J., Cheng, H., Edwards, R.L., An, Z.S., Wu, J.Y., Shen, C.-C., Dorale, J.A., 2001. A highresolution absolute-dated late Pleistocene monsoon record from Hulu Cave, China. Science 294, 2345-2348.

Wang, Y.J., Cheng, H., Edwards, R.L., Kong, X.G., Shao, X.H., Chen, S.T., Wu, J.Y., Jiang, X.Y. Wang, X.F., An, Z.S., 2008. Millennial- and orbital-scale changes in the East Asian monsoon over the past 224000 years. Nature 451, 1090-1093.

Weckström, K., Weckström, J., Yliniemi, L.-M., Korhola, A., 2010. The ecology of Pediastrum (Chlorophyceae) in subarctic lakes and their potential as paleobioindicators. J. Paleolimnol. 43, 61-73.

Wei, H.C., Ma, H.Z., Zheng, Z., Pan, A.D., Huang, K.Y., 2011. Modern pollen assemblages of surface samples and their relationships to vegetation and climate in the northeastern Qinghai-Tibetan Plateau, China. Rev. Palaeobot. Palynol. 163, 237-246.

Whitney, V.S., Mayle, F.E., 2012. Pediastrum species as potential indicators of lake-level change in tropical South America. J. Paleolimnol. 47, 601-615.

Winkler, M.G., Wang, P.K., 1993. The late-Quaternary vegetation and climate of China. In: Wright, H.E., Kutzbach, J.E., Webb III, T., Ruddiman, W.F., Street-Perrott, F.A., Bartlein, P.J. (Eds.), Global Climates Since the Last Glacial Maximum. University of Minnesota Press, Minneapolis, MN, pp. 221-264.

Xu, Q.H., Li, Y.C., Yang, X.L., Xiao, J.L., Liang, W.D., Peng, Y.J., 2005. Source and distribution of pollen in the surface sediment of Daihai Lake, Inner Mongolia. Quat. Int. 136, 33-45.

Yang, W.B., Spencer, R.J., Krouse, H.R., Lowenstein, T.K., Casas, E., 1995. Stable isotopes of lake and fluid inclusion brines, Dabusun Lake, Qaidam Basin, western China: hydrology and paleoclimatology in arid environments. Palaeogeogr. Palaeoclimatol Palaeoecol. 117, 279-290.

Yu, S.S., Liu, X.Q., Tan, H.B., Cao, G.C., 2009. Sustainable Utilization of Qarhan Salt Lake Resources. Science Press, Beijing, pp. 27-265.

Zhang, P.X., 1987. Salt Lake in Qaidam Basin. Science Press, Beijing, pp. 1-235.

Zhang, P.X., Zhang, B.Z., Lowenstein, T.K., Pancer, R.J., 1993. Origin of Ancient Potash Evaporites: Examples From the Formation of Potash of Qarhan Salt Lake in Qaidam Basin. Science Press, Beijing, pp. 27-121.

Zhang, H., Zheng, Z., Wang, J.H., Wang, B., Deng, Y., Zou, H.P., 2004. Climate changes for last 2500 years based on Pediastrum record from Hainan Island. Trop. Geogr. 24 (2), 109-1122 (in Chinese).

Zhang, H.C., Lei, G.L., Chang, F.Q., Fan, H.F., Yang, M.S., Zhang, W.X., 2007. Age determination of Shell Bar section in Salt Lake Qarhan, Qaidam Basin. Quat. Sci. 27 (4), 511-521 (in Chinese).

Zhao, Y., Herzschuh, U., 2009. Modern pollen representation of source vegetation in the Qaidam Basin and the surrounding mountains, north-eastern Tibetan Plateau. Veg. Hist. Archaeobotany 18, 245-260.

Zhao, Y., Yu, Z.C., Chen, F.H., Ito, E., Zhao, C., 2007. Holocene vegetation and climate history at Hurleg Lake in the Qaidam Basin, northwest China. Rev. Palaeobot. Palynol. 145 275-288.

Zhao, Y., Yu, Z.C., Chen, F.H., Liu, X.J., Ito, E., 2008. Sensitive response of desert vegetation to moisture change based on a near-annual resolution pollen record from Gahai Lake in the Qaidam Basin, northwest China. Glob. Planet. Chang. 62, 107-114.

Zhao, Y., Li, F.R., Hou, Y.T., Sun, J.H., Zhao, W.W., Tang, Y., Li, H., 2012a. Surface pollen and its relationships with modern vegetation and climate on the Loess Plateau and surrounding deserts in China. Rev. Palaeobot. Palynol. 181, 47-53.

Zhao, Y., Liu, H.Y., Li, F.R., Huang, X.Z., Sun, J.H., Zhao, W.W., Herzschuh, U., Tang, Y., 2012b. Application and limitation of Artemisia/Chenopodiaceae pollen ratio in arid and semiarid China. The Holocene 22 (12), 1385-1392.

Zheng, Z., Wang, J.H., Wang, B., Liu, C.L., Zou, H.P., Zhang, H., Deng, Y., Bai, Y., 2003. High resolution climate records during Holocene from Maar Lake of Shuangchi in Hainan Island. Chin. Sci. Bull. 48 (3), 282-286.

Zheng, Z., Huang, K.Y., Xu, Q.H., Lv, H.Y., Cheddadi, R., Luo, Y.L., Beaudouin, C., Luo, C.X. Zheng, Y.W., Li, C.H., Wei, J.H., Du, C.B., 2008. Comparison of climatic threshold of geographical distribution between dominant plants and surface pollen in China. Sci. China Ser. D 51 (8), 1107-1120.

Zheng, Z., Yang, S.X., Deng, Y., Huang, K.Y., Wei, J.H., Berne, S., Suc, J.P., 2011. Pollen record of the past $60 \mathrm{ka} \mathrm{BP}$ in the Middle Okinawa Trough: terrestrial provenance and reconstruction of the paleoenvironment. Palaeogeogr. Palaeoclimatol. Palaeoecol. 307, 285-300. 